\title{
Periungual tegumentary leishmaniasis: a diagnostic challenge*
}

\author{
Bruna Morassi Sasso ${ }^{1}$ \\ Andréa Fernandes Eloy da Costa França ${ }^{1}$
}

\author{
Ana Beatriz Barbosa Torino ${ }^{1}$ \\ Paulo Eduardo Neves Ferreira Velho ${ }^{1}$
}

\section{DOI: http://dx.doi.org/10.1590/abd1806-4841.20176352}

\begin{abstract}
Periungual and paronychia-like skin lesions can mimic various diseases, setting up a diagnostic challenge that invariably requires correlation with complementary tests. We report a case of an ulcerated tumor of the nailfold diagnosed as leishmaniasis. Although paronychia-like cutaneous leishmaniasis is a rare variant, its epidemiological relevance in Brazil should prompt dermatologists to include it as a plausible diagnosis thus leading to correct work up and treatment.
\end{abstract}

Keywords: Nails; Paronychia; Leishmaniasis, cutaneous

A 23-year-old Caucasian man, forestry technician, living in the southwestern area of the state of São Paulo, presented with a lesion in the distal phalanx of the 5 th left chirodactyl that had been present for 2 months, with ipsilateral axillary lymphadenopathy and a lymphatic cord that regressed spontaneously.

The dermatological evaluation showed edema of the 5th left chirodactyl with tumoral erythematous lesion on the palmar and dorsal surface of its distal phalanx, ulcerated area close to the proximal nail fold, as well as tumor on the hyponyxic with meliceric crust and onycholysis (Figure 1). Lymph nodes were not palpable, including in the epitroclear and axillary left chains.

The anatomopathological examination evidenced an important epidermal hyperplasia with dense chronic interstitial inflammatory process rich in plasmocytes, with granulomatous reaction and structures suggestive of leishmaniasis (Figures 2 and 3).

The Montenegro reaction was positive $(15 \mathrm{~mm})$, and correlation of clinical and laboratory findings allowed the dianosis of paronychia-like cutaneous leishmaniais. ${ }^{1,2}$

Treatment with N-methyl glucamine antimonate $15 \mathrm{mg} /$ $\mathrm{SbV} / \mathrm{kg} /$ day for 20 days was started, with resolution (Figure 4, A and B). ${ }^{3}$

\section{DISCUSSION}

Paronychia-like lesions are challenging because they resemble several pathologies and the diagnosis usually occurs through clinical correlation with complementary examinations. ${ }^{4-9}$ Differential diagnoses should be considered as inflammatory, infectious or

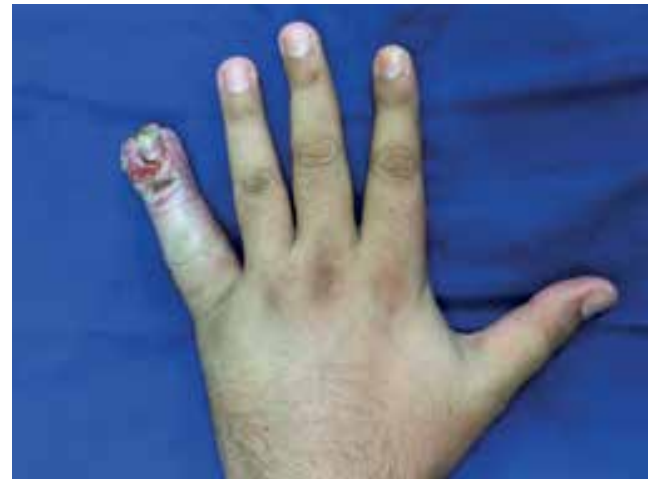

FIGURE 1: Edema of the 5th left chirodactyl, with erythematous lesion on the distal phalanx, tumoral and ulcerated, with granular base, with paronychia and onycholysis, bypassing diffusely all nails folds with ill-defined limits. Presence of light hypochromic macula in the medial phalanx poorly delimited

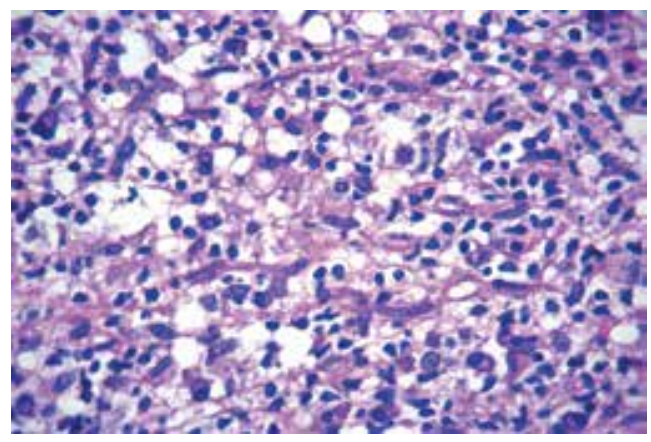

FIGURE 2: Hematoxylin and Eosin (x500): Granulomatous reaction, rich in plasma cells 


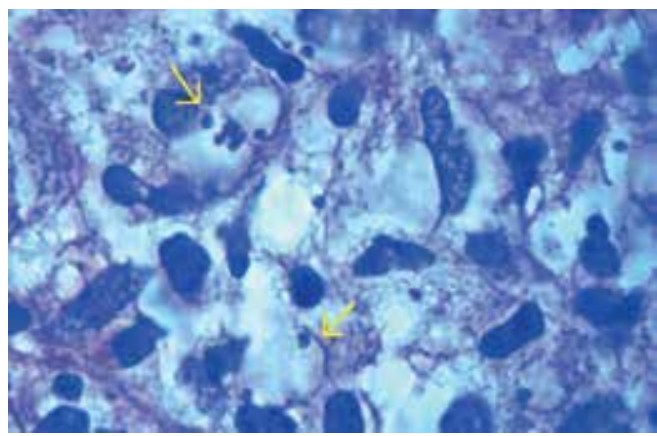

FIGURE 3: Giemsa (x1250): Intracellular structures with eccentric nucleus suggestive of amatigote form of leishmania (arrow)

neoplastic causes. ${ }^{4}$ In the case reported, the main hypothesis was sporotrichosis, with unexpected diagnosis of leishmaniasis.

Leishmania (Viannia) braziliensis is the most prevalent species in cases of mucocutaneous leishmaniasis in Brazil and antimo-

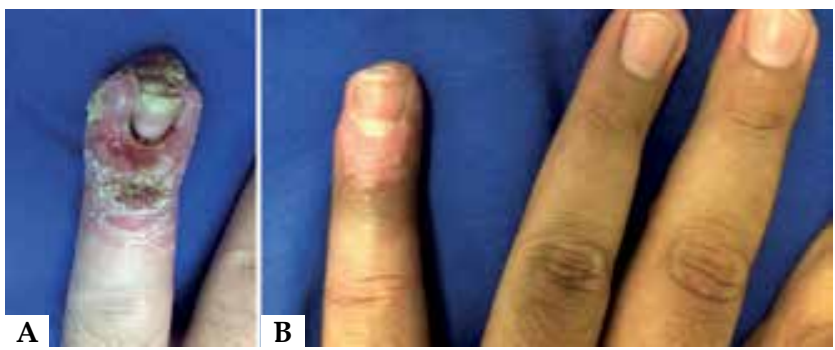

Figure 4: A. Before treatment B. One month after the discontinuation of antimonial treatment

nials are the first line therapeutic agents. Topical treatment is controversial. ${ }^{10}$ In the epidemiological context, the therapeutic modality and the diagnosis by the visualization of the parasite are indispensable in paronychial cases. ${ }^{1,10}$

\section{REFERENCES}

1. Desjeux P. Leishmaniasis: current situation and new perspectives. Comp Immunol Microbiol Infect Dis. 2004;27:305-18.

2. Brasil. Ministério da Saúde. Secretaria de Vigilância em Saúde. Manual de Vigilância da Leishmaniose Tegumentar Americana. 2 ed. Brasília: Editora do Ministério da Saúde; 2010. 180 p - (Série A. Normas e Manuais Técnicos).

3. Savoia D. Recent updates and perspectives on leishmaniasis. J Infect Dev Ctries. 2015 Jul 4;9(6):588-96.

4. Duhard E. Les paronychies. Presse Med. 2014;43:1216-22.

5. Iftikhar N, Bari I, Ejaz A. Rare variants of Cutaneous Leishmaniasis: whitlow, paronychia, and sporotrichoid. Int J Dermatol. 2003;42:807-9.

6. Raja KM, Khan AA, Hameed A, Rahman SB. Unusual clinical variants of cutaneous Leishmaniasis in Pakistan. Br J Dermatol. 1998;139:111-3.

7. Chaabane H, Turki H. Images in clinical medicine. Cutaneous leishmaniasis with a paronychia-like lesion. N Engl J Med. 2014;371:1736.

8. Chiheb S, El Machbouh L, Marnissi F. Paronychia-like cutaneous leishmaniasis. Dermatol Online J. 2015 ;21. pii: 13030/qt70f8b1t8.

9. Gomes CM, Morais 00, Leite AS, Soares KA, Motta Jde 0, Sampaio RN. Periungual leishmaniasis. An Bras Dermatol. 2012;87:148-9.

10. de Vries HJ, Reedijk SH, Schallig HD. Cutaneous leishmaniasis: recent developments in diagnosis and management. Am J Clin Dermatol. 2015;16:99-109.

\author{
MAILING ADDRESS: \\ Bruna Morassi Sasso \\ Cidade Universitária Zeferino Vaz \\ R. Vital Brasil, 251 - Cidade Universitária \\ 13083-888 - Campinas - SP \\ Brazil \\ Email:b_morassi@yahoo.com.br
}

How to cite this article: Sasso BM, Torino ABB, França AFECF, Velho PENF. Periungual tegumentary leishmaniasis: a diagnostic challenge. An Bras Dermatol. 2017;92(2):268-9. 